\title{
Challenges of Higher Education in India - Issues, Role and Recommendations
}

\author{
Arunima Kumari* \\ Dr R P C A U, Pusa, Samastipur, 848125 Bihar, India \\ *Corresponding author
}

\section{A B S T R A C T}

\section{Keywords}

TER $=$ Total Enrollment Rate, UGC= University Grant Commission, RAU $=$ Rajendra Agricultural University

\section{Article Info}

Accepted: 16 April 2018 Available Online: 10 May 2018

India especially the state of Bihar was a place of learning where about 20000-50000 students from all over the world were coming to gain knowledge in various world famous Universities of Nalanda and Vikaramshilla where about 10,000 teachers were residing day $\&$ night in search of new thoughts and theories of life. The value of $\boldsymbol{\pi}$ and 0 were invented by none other than an Indian astrologer. Then in medieval history due to some socio economical factors it was diminished somehow and the spread of literacy and education got affected. During colonial era Macaulay's system of education was imposed just to produce clerks. Today with 740 Universities, 33023 Colleges and more than 18 million students, education network of India is the $3^{\text {rd }}$ largest network in the world after China and USA. But it is very hard to note that India is lagging behind in enrollment ratio in world scenario. The purpose of study was to know the present scenario of higher education in India, to analyze its challenges and suggest recommendations for further improvement. The information and data have been collected from secondary data, official website of UGC, other related published papers, seminar reports, books, economic survey of India and views were collected from P. G. students of Dr R P C A U too. Age old culture of intellectual enquiry has been replaced by performance indicators, quality assurance, and quantitative output and all have encompasses the universities into a stressful union. The challenges of higher education have become a matter of concern not only in India but in all over the world. It has become a question of utmost importance that what policies should be followed by the institutions of higher education which can prepare the future of world with a steel determination to face the upcoming situation.

\section{Introduction}

India was supposed to be a place of learning for the students from all over the world about 600 B.C where Nalanda and Vikramshila were the two greatest Universities where students from around the world were coming to gain knowledge. These two world fame
Universities were famous not for disseminating knowledge in only one subject but in the field of Sanskrit, Pali, AstroPhysics, Metallurgy, Geography, Medicines, Art and Culture and all other fields what were related to life and nature. During those early days pupil were learning by listening from their Guru's and by practicing those principles 
in their life in real sense. It means learning was practical oriented and one can call it today's pedagogical method of learning.

But with the turn of civilization teaching and learning also changed and then there was deterioration in teaching learning situation and in result enrollment rate also decreased at mass level because there was a state of anarchy in the country, during post medieval history or Muslim governance. After post medieval history India was under British rule and they were in dire need of clerk or Babus so they imposed Macaulay's system of education upon us.

But till we got Independence there was not a much improvement in the enrollment rate or total literacy percentage. It was an herculean task in front of our policy makers to educate such a huge group of uneducated mass, hence during $1^{\text {st }}$ five year plan this area was much focused and in 1950-51 there were 28 universities 695 colleges and 1,74,000 students. Today we have about 342 state Universities 125 deemed Universities, 46 Central Universities, 227 private Universities, (altogether 740) as per UGC 2014-15 report but as per 2011-12 data there were only 659 Universities and 33023 colleges. Today, although India is having the maximum no. of technocrats but when we look into the gross enrollment ratio then the scene is pathetic, we mark only $20 \%$ in world whereas average GER worldwide is considered to be $30 \%$. Amongst the 1.2 billion people $44 \%$ of the population comprises of children. India spends only 3.3 of its GDP on education the dropout rate in primary school is very high its $50 \%$ for boys and 58\% for girls (Report of facts on education2014).

\section{Objectives of this study were as follows}

To analyze the development and present scenario of higher education in India.
To focus on role of higher education in India to increase its economic output and strengthen its overall development.

To discuss the major issues related to the topic.

To suggest recommendation for further improvements.

\section{Materials and Methods}

This study was focused to discuss the challenges what India is facing today, various issues related to higher education, its role and suggestive recommendations the data and information were collected through various sources of secondary data viz., various websites of ministry of HRD, UGC different related papers and the feedback from the post graduate students of our own Universities.

\section{Role and challenges of higher education in India}

Education is a total metamorphosis of human being, it's a change in the uncivil behavioral pattern into a civic one, it paves the way towards total constructive behavioral change in a human being, it is not only to gain knowledge to read or write a few alphabets, numerical or few Hindi words.

Education Commission recently observed that "Education is the key enabler for the development of an individual and for altering the Socio economic landscape of a country". About a century ago guru $\mathrm{R} N$ Tagore described the Universities as the place for "a common pursuit of truth" a place where, perhaps a bit like a cricket team, we are all in it together. India, despite having the third largest University system in the world generating an estimated 14\% of the global talent pool, faces a serious shortfall of top talent for its developing economy. 
Higher education institutions are currently undergoing a global transformation process in all contexts although with specific characteristics in different parts of the world. The role of higher education institutions in society will influence the place of knowledge in facing the challenges the world faces today and at the same time this will influence higher education institutions impact and opportunities to contribute to build a better world. Higher education faces the challenges of creating and distributing socially relevant knowledge and of doing it with anticipation so as to play a proactive and committed role in the transformation and positive changes of societies.

Therefore, there is a need to reconsider what the social contribution of higher education should be Global Universities Network 2014.

The benefits of attending colleges are being seriously curtailed by recent changes in higher education including expansion of the public sector, the trend towards larger institutions, and the de-emphasis on residential experience (Alexander, 1977).

This is not an especially happy time for higher education worldwide. Academe is everywhere under attack. University leaders, have been unable to defend the institution successfully from the critics and from governments committed to cutting budgets and shifting governmental priorities. The academe country does not speak it all. The contemporary Universities must present a vision of its role in the future and defend its part contributions to knowledge and to society (Philip G. Altbach, 1973).

Despite all this, Universities on my own view will never lost its importance in near future due to their demand for academic degrees and credentials and the role of the University in providing training for most professional fields will continue. Research will continue to be produced as part of the role of the academic profession and of the University. The University will continue to be one of the societies' most valued institutions.

In one sense, the $\mathrm{U} \mathrm{S}$ is in the vanguard in terms of responding to some of the most serious problems of higher education and other countries are moving increasingly in on "American" direction. This is due to not only to the political and economic power of the U.S. But to the fact that there is an international current towards ever larger enrollments in institutes of high education and the American University was the first to move to a "mass" and now an increasing Universal system of postsecondary education; Trow, 1972, Other countries are now moving at various speeds towards "mass" postsecondary system (Bereday, 1973).

Gupta Deepali and Navneet Gupta (2012) mentioned in her paper "Higher education in India" that India's education system is often cited as one of main contributors to the economic rise in India, The size of higher education in India market is about 40 billion \$ per year. Presently about $12.5 \%$ of students go for higher education if India were to increase that figure of $12.4 \%$ to $30 \%$ then it would need another 802 to 1000 Universities and over 40000 Colleges in the next ten years.

Gross enrollment ratio in India is at primary level is $92 \%$, Gross enrollment ratio in higher education level is $20 \%$, Gross enrollment ratio at secondary level is $52 \%$, the average Gross enrollment ratio worldwide is considered to be $30 \%$ and India is lagging behind in it with $20 \%$ Gross enrollment ratio only. Amongst the 1.2 billion people $44 \%$ of the population comprises of children. India spends only 3.3\% of its GDP on education. The dropout rate in primary schools is very high. It is $50 \%$ for boys and $58 \%$ for girls, 
(www.dnaindia.com/India/report-grossenrollment - survey report).

\section{Results and Discussion}

The results found in collection of data have been listed as major challenges:-

\section{Lack of infrastructure facilities}

Still one can very well visualize a college and school without proper laboratories facilities and proper upto date libraries in rural India. About $59 \%$ of secondary schools in India don't have an integrated science laboratory, just $32 \%$ schools have separate rooms for laboratories and a quarter of them are 'partially equipped'. Just $37 \%$ of schools have a computer with net connection (Times of India Jan. 10, 2016). According to a recent report of HRD Ministry premier educational institutes like the Indian Institute of Technology (IITs) and the Indian Institute of Management (IIMs) are facing a faculty crunch with nearly one- third of the posts vacant. According to a report published in IANS around 35 percent posts are vacant in the central universities, 25 percent in the IIMs, 33.33 percent in the National Institute of Technology (NITs) and 35.1 percent in other central education institutions coming up under the Human Resource Development (HRD) Ministry However in order to overcome this, government is planning to have short-term measures like raising the retirement age in teaching posts from 62 to 65 years and enhancement in salaries and other benefits for teachers.

\section{Wide gap between demand and supply}

There is a wide gap between and supply in respect to availability of teachers and vacant post of teachers/ professors in higher institutes of learning. Addressing a higher education summit organized by the Federation of Indian
Chambers of Commerce and Industry (FICCI), HRD Minister Kapil Sibbal said "We will need 800 new universities and 40,000 new colleges to meet the aim of 30 percent GER (gross enrolment ratio) by 2020. Government alone cannot meet this aim," Statistics show that there is a huge gap between the demand and supply. The HRD ministry says that the foreign institutions could fill this gap to a large extent. Close to 50 Foreign universities may enter India in near future. But realistically speaking, the foreign institutions could not fill this gap. This is the third attempt being made by government to liberalize education system. Two attempts were made in 1995 and 2006 to bring foreign universities to India. Against the projected requirements, the 11th Five Year Plan [7-8] provides for a total of 30 new Central Universities (with medical and Engineering colleges), eight new IITs, 20 NITs, 20 IIITs, 3 IISERs, seven IIMs, and two SPA and 373 new colleges in districts with GERs that are below the national GER.

\section{Quality education}

Quantity and quality of highly specialized human resources determine their competence in the global market. According to a recent government report two-third of India's colleges and universities are below standard. However, according to MHRD annual report 2009-10 a proposal for Mandatory accreditation in higher education and creation of an institutional structure for the purpose of regulation is under consideration. India's highest-quality institutions have severely limited capacity. In order to increase the supply quality should be maintained. Recently MRD ministry has decided to derecognize as many as "44 deemed universities". These 44 deemed universities have 1,19,363 students at the undergraduate and postgraduate levels. In addition, there are 2,124 students pursuing research at M-Phil and $\mathrm{PhD}$ levels and another estimated 74,808 students pursuing distance 
education programmes. As many as 41 of the 44 deemed universities have several constituent institutions under them, which would further swell the number of affected students.

\section{Research and development}

In early days during Vedic era our education system was based on day to day needs and that's why today's medicine science, surgery was developed by the great Charak and Sushurat. After a long tenured research of medicines today medicine science originated, same was with metallurgy and other Endeavour of art and science. But today's institutions are lacking somehow in this respect and only age old researches are being copied. Hence, there is a dire need that teacher should encourage students to innovate new ideas and do basic researches related to our day to day life. Research and higher education are complementary to each other. According to the available official statistics the expenditure on $\mathrm{R}$ and $\mathrm{D}$ in the field of Science and Technology as a percentage of gross domestic product (GDP) was 0.8 percent during the year 2005-06 in India. For perspective, countries spending the most on $\mathrm{S}$ and $\mathrm{T}$ as a percent of their GDP were Israel 5.11 percent, Sweden 4.27 percent, Japan 3.11 percent, South Korea 2.95 percent, the United States 2.77 percent, Germany 2.74 percent and France 2.27 percent. Among other countries, China 1.54 percent, Russia 1.74 percent, U.K. 1.88 percent and Brazil 1.04 percent have spent more than India.

Moreover, India's higher education institutions are poorly connected to research centers. So this is another area of challenge to the higher education in India.

In nutshell it can be concluded that there is a wide scope to do a lot in this area, and there is a massive scope of new research too concern with this topic.

\section{Total No. of higher institution in India}

\begin{tabular}{|c|}
\hline Universities \\
\hline State Universities \\
\hline Deemed to be Universities \\
\hline Central Universities \\
\hline Private Universities \\
\hline Total \\
\hline
\end{tabular}

\section{Recommendations}

There is need of annual assessment / accreditation on various parameters like infrastructure, teaching strength, student strength, overall performance, Teaching learning situation and departmental assessment should be done.

As institutes are the temple of learning wisdom and knowledge hence students should

\section{Total}

342

125

46

227

740

Source- UGC 2014-15 Report

not be demarcated on the basis of caste line. If at all any reservation policy has to be followed then it should be based on the economic condition of the students.

Because at the very grass root level meritorious students should not face any type of frustration due to unjustified reservation policy followed in the country. Professor of the government Universities should follow the handsome salary and incentive packages like 
private institutes so that brain drain of the skilled professors will be stopped.

A curriculum incorporated with high moral value should made necessary for all the institute because a good character has positive impact on total growth of the country.

Government institutes would have to reshape its academic environment to come at par with private institutes.

Courses based on present day need should be incorporated instead of only those traditional courses which are not needed by industry, Agriculture or other sector.

The government of India should permit grantin - aid basis professional colleges instead of non- grant base colleges.

Time to time students as well as other teaching and non-teaching staff should be sent for exposure visit for their professional development, without following any kind of biasness.

\section{References}

Austin, Alexander W, 1977.

Chakraborty KC (Deputy Governor of RBI), "Indian Education System: Issues and Challenges," address at the JRE School of Management, Greater Noida, $5^{\text {th }}$ August, 2011.

Deepali Gupta, Navneet Gupta, Higher Education in India structure statistics and challenges, Journal of Education and Practice; vol 3 No. 2, 2012.
Global Universities Network for Innovation C. Sant Antoni Maria Claret 167 Pav. Sant Leopols 51, Recinte Historic de sant pau 08025 Barcelena 2014.

Jossey Bass- Publication, Inc 615, Inc 615 Montgomery street, Sam Francisco, California 94111.

Ministry of Human Resource Development MHRD, Annual Report on Higher Education in India- 2014.

Other countries are now moving at various speeds towards "mass" postsecondary system Bereday 1973.

Philip G. Altback: Comparative higher education: Knowledge the University and Development, Report published by AA of higher education Washington D.C. 1973.

Report of Education Commission 2014.

Satish Modi Higher Education in India: Issues and Challenges; academe VI XVII, No. 1. January 2014.

Subodh. Verma "If Indian Science Congress is a Joke, It's Because Science is a Tragedy. Sunday Times of India, Patna, Page 06 Col. 03 January 10, 2016.

Universal system of postsecondary education (Trow 1972, pp. 61-84).

University Grant Commission, Higher Education in India: Strategies and Schemes during Eleventh Plan Period (2007-12) for Universities and Colleges.

University Grant Commission: "Higher Education in India: UGC report 201415 " for Universities and Colleges.

www.giftafuture.org/factsoneducationhttp://w ww.dnaindia.com/India/Report-grossenrollment-ratio-recorded-at-188-inIndia-survey.

\section{How to cite this article:}

Arunima Kumari. 2018. Challenges of Higher Education in India - Issues, Role and Recommendations. Int.J.Curr.Microbiol.App.Sci. 7(05): 1786-1791. doi: https://doi.org/10.20546/ijcmas.2018.705.209 